doi: $10.26529 /$ cepsj. 1274

\title{
Editorial
}

\section{The Contexts and Processes of Shaping Teacher Identity}

The importance of studying teachers' personal and professional identities has gained significant attention in recent decades, given the need to understand better the rationale behind teachers' behaviour in their tasks. In light of this, research has aimed to examine the meaning of the professional identity of teachers and recognising the importance of various professional circumstances. We know that teachers' professional identity is understood as an active and changing process influenced by individual personality and internal factors, as well as external factors (Beauchamp \& Thomas, 2009; Beijaard et al., 2004; Schepens et al., 2009). However, research has yet to provide insights in greater depth on the meaning of system variables and professional factors related to the development of teacher identity as they occur in the ever-changing education system and schools.

Two notions will be important for the present and future research on teacher identity development. First is the concept of stability and relativity. Though research has come to a common understanding of what teacher identity is and how it is formed, it is still an evolving concept and needs further research to provide policymakers and practitioners with a clear view of how to deal with such a changing situation.

In addition, we have also arrived at the point at which it is important to note that shaping teacher identity is closely linked to the debate on evolving teacher professionalism. Teacher identity is nowadays also influenced by how expectations regarding teacher behaviour and expectations on the profession of teaching have continually increased. Therefore, it is unavoidable that the debate on post-modern professionalism (See Hargreaves, 2000) is directly correlated with the need to reshape the professional identity of teachers in light of the new professionalism as it continues to evolve.

However, it is school context variables such as school culture and accountability mechanisms in place that determine the dynamics and processes of shaping teacher practices and professional behaviours. This focus issue has attempted to emphasise the need for adopting this much broader view on teacher professional identity development. This focus issue includes five articles that directly relate to the topic of this issue. The ordering of articles is also linked to the simple logic of framework variables that can serve future research agendas. This new framework of understanding teacher identity is composed of dimensions of the identity and practices of teacher educators; the practical side of training new teachers in campus and school; the importance of context and experiences 
in enriching teacher identity; the ways global policymaking and benchmarking processes influence the policy design in teacher education and practice; and a view of the practical side of curriculum planning and implementation as a way of demonstrating professional identity in practice.

The first article in this focus issue is centred on the notion of who teacher educators are and the importance of their approach to tasks in relation to training prospective teachers. In other words, noting the importance of the role teacher educators play in shaping the identity of prospective teachers. Sotiria Pappa and Josephine Moate, in their article "Teacher Educators' Professional Identity in English-Medium Instruction at a Finnish University" emphasises the importance of pedagogical being, pedagogical doing, and pedagogical relating as three key dimensions of understanding teacher educator practice in relation to preparing new teachers.

The focus issue continues with the article from Gemma Torres-Cladera, Núria Simó-Gil, Laura Domingo-Peñafiel, and Vanesa Amat-Castells, titled "Building Professional Identity During Pre-Service Teacher Education" by emphasising the role pre-service teacher education (including school placement experience) has in shaping teacher identity. The article emphasises relationship building and reflection as important dimensions and the need to empower university-based training and school placement experience connections, as well as how university tutors can support a coherent approach.

The third article continues examining the identity formation of student teachers and how student teachers take up temporary identities in given contexts in relation to the contextual factors in which they are embedded. It is written by Alexander S. Butler and is titled "The Impact of External Contextual Factors on Teaching Candidates". It raises an important question for future research as to how these temporary identities shape and are internalised as part of the core identity features.

The fourth article brings a new perspective and approach to examining the development of teacher identity at the policy and global levels. It is authored by Armend Tahirsylaj, William C. Smith, Gulab Khan, and Wieland Wermke and is titled "The Conceptual and Methodological Construction of a 'Global' Teacher Identity through TALIS". This article examines how major education policy players, such as the OECD, through various assessment and benchmarking processes, such as TALIS, contribute to the development of global teacher identity or, in other words, shape the meaning of teacher effectiveness.

Finally, the last focus issue article written by Petra Brdnik Juhart and Barbara Sicherl Kafol examines the personal and professional competencies of music education teachers in the use of authentic situations. It demonstrates 
how teacher identity is also shaped by not only competencies but also by engaging in the practical side of curriculum planning and enacting.

This focus issue also includes three articles in the Varia section. The first article is authored by Naser Zabeli, Blerta Perolli-Shehu, and Jeffrey A. Anderson titled "The Understanding of Inclusive Education in Kosovo: Legal and Empirical Argumentation". It describes the experience of Kosovo in transitioning towards inclusive education and how this experience has influenced teacher understanding of inclusive education. The second Varia section article "Teachers' Self-Efficacy Based on Symptoms of Attention Deficit Hyperactivity Disorder in Primary School Pupils" authored by Nataša Vlah, Tena Velki and Emina Kovačić examines teacher self-assessment of efficacy in relation to working with pupils with learning difficulties and, more specifically, students who have ADHD. The third and final Varia article is titled "Translation and Validation of the Kaufman Domains of Creativity Scale on a Croatian Sample of Early Childhood and Preschool Education Students" and is authored by Marijana Županić Benić. It reports on the validation of the Kaufman Domain of Creativity Scale in the Croatian context and identifies next steps in determining the validity of the adapted questionnaire.

This Varia section also includes two book reviews. The first was written by Romina Plešec Gašparič on the book 'Instructional methods and the teacher's methodical competence' authored by Milena Valenčič-Zuljan and Jana Kalin (In Slovene language: Učne metode in razvoj učiteljeve metodične competence; Pedagoška fakulteta UL). The second book review was written by Mija M. Klemenčič-Rozman and was related to the book 'Child Protection from violence and neglect in Slovenia, authored by Vesna Leskovšek, Tadeja Kodele and Nina Mešl (Eds.) (In Slovene language: Zaščita otrok pred nasiljem in zanemarjanjem v Sloveniji; Fakulteta za socialno delo UL).

\section{Blerim SAqipi ANd JANEZ Vogrinc}

\section{References}

Beauchamp, C., \& Thomas, L. (2009). Understanding teacher identity: An overview of issues in the literature and implications for teacher education. Cambridge Journal of Education, 39(2), 175-189. Beijaard, D., Meijer, P. C., \& Verloop, N. (2004). Reconsidering research on teachers' professional identity. Teaching and Teacher Education, 20, 107-128.

Hargreaves, A. (2000). Four ages of professionalism and professional learning. Teachers and Teaching: History and Practice. 6(2), 151-182.

Schepens, A., Aelterman, A., \& Vlerick, P. (2009). Student teachers' professional identity formation: between being born as a teacher and becoming one. Educational Studies, 35, 361-378. 